\title{
Piracy and Slave Trading in Action in Classical AND HELLENISTIC GREECE*
}

David M. Lewis ${ }^{1}$

\begin{abstract}
Most slaves in the Greek world were imported non-Greeks and their offspring. Yet little is known of the entry into slavery of individuals from the non-Greek periphery. Far more promising for studying entry into slavery is a less numerically significant process, piracy, where the capture and sale of individuals - mainly Greeks - is extensively documented. Piracy was both a form of labour in itself, and a means of acquiring labour. The aim of this article is to explore the pragmatic aspects of capture and sale, as well as the extent to which the practice of ransoming prisoners kept captives away from entering the slave supply, by studying the pirate crew's work, the technology at its disposal, and the fate of its victims.
\end{abstract}

KEYWORDS: Piracy; Slavery; Slave Trade; Ransom; Labour.

The Classical and Hellenistic slave supply comprised a complex mesh of trade routes, markets, and merchants, whose commodity - enslaved human beings - was fed into this network by a variety of processes. Of the several mechanisms by which individuals can enter slavery (see Lewis, 2016, p. 318), virtually all can be seen in play in the Greek world, their relative significance fluctuating from place to place and shifting across time. Amid this flux, though, we can track some fairly consistent and high-volume currents of enslaved humanity operative over the long term. For example, slaves from Anatolia, especially Phrygia, regularly appear in our sources (and often in significant numbers) from the sixth century BC through to the Roman period, as do slaves from the Black Sea and Thrace. ${ }^{2}$

\footnotetext{
* My thanks to Lilah Grace Canevaro, Mirko Canevaro, Edward Harris, and Jim Roy for reading and commenting on drafts of this essay. My thanks too to Keith Rutter for the invitation to address the Scottish Hellenic Society of Edinburgh (October 2015) and to the audience for their comments; none of the above are to be held responsible for this essay's shortcomings. Translations are my own unless otherwise noted; in cases where vessels are named with Latin and Greek variants (e.g. lembus/lembos), I tend to favour the Greek version. Finally, I would like to thank Prof. Boris Rankov and the Trireme Trust for permission to reproduce figure 1 on p. 87, and to my friend Gabriel Cabral Bernardo for the invitation to submit this essay to Mare Nostrum. This essay is dedicated to the memory of my grandfather, Lt. Cdr. M. E. Lewis RN.

${ }^{1}$ Lecturer in Greek History and Culture, Department of Classics, the University of Edinburgh, Scotland. E-mail: david.lewis@ed.ac.uk.

${ }^{2}$ Anatolia, esp. Phrygia: see Lewis, 2011; 2016; 2018a; 2018b, p. 277-286. Black Sea and Danubian regions: Finley, 1962; Avram, 2007; Fischer, 2016; Thrace: Velkov, 1964.
} 
However, when it comes to reconstructing the processes of enslavement and the supply chains that linked these "barbarian" sources with buyers in the marts of the Aegean city-states, we are at once confronted with the limitations of our evidence: though detailed in places, it is extremely patchy when taken in aggregate, with vital parts of the puzzle missing.3 Indeed, despite the numerical importance of Thracian and Phrygian slaves, it is next to impossible to write a social history of their initial enslavement and entry into the domain of commercial transactions, or at least a detailed one. We have a case for greater optimism, though, regarding one of the less numerically significant processes of enslavement in the Greek world: piracy. 4 This article explores the entry of individuals into slavery by sketching the practical aspects of kidnap and sale that, over many centuries, removed thousands of individuals into a life of slavery. Recent work has stressed the need to reconstruct the social lives of slaves by examining their networks of interaction and experiences beyond the asymmetrical owner-slave dialectic (e.g. Vlassopoulos, 2011). We do not possess for antiquity the sort of narratives that survive for the Early Modern period whereby individuals related their kidnap and sale by Barbary corsairs; 5 nor can we reconstruct the social history of slaves in transit with anything like the degree of detail achieved in, say, Rediker's The Slave Ship: A Human History (2007). ${ }^{6}$ But by piecing together the data scattered throughout our sources, we can at least construct a framework that allows us to understand better the initial stages of this branch of the slave supply, and the experiences of individuals thus enslaved.

This essay will address our topic in two parts. Part I examines Greek piracy from the vantage point of the pirate crew and analyses its work, examining the technology at its disposal and how it was put into use. Much important work has been published in recent years on various facets of ancient piracy, 7 but one

3 I have essayed a reconstruction (admittedly, sketchy) of the Anatolian-Aegean trade in Lewis, 2016; further thoughts in Lewis, 2018b, p. 277-286.

4 That piracy was not a first-rank source of slaves in the Greek world has been convincingly shown by Garlan, 1987.

5 Vitkus, 2001; see also Milton, 2004.

${ }^{6}$ Besides, the duration of ancient Eastern Mediterranean voyages was much less than the Atlantic routes discussed by Rediker (see in general Arnaud 2005); and there is no reason to believe in specialized slave ships for the Greek world.

7 For the political/historiographical facet, see Avidov, 1998; de Souza, 1999; Wiemer, 2002; Criscuolo, 2013. For the socio-economic facet, see Gabrielsen, 2001; 2003; 2013a; 2013b. For a comparative approach, see Rauh, 1997. See also Perrier, 2008 and the recent edited volumes of Braccesi, 2004; Grieb and Todt, 2012; Jaspert and Kolditz 2013. 
notable area of neglect lies in the pragmatic issue of how it played out in practice. Various contributions have been made over the years regarding the technical attributes of this or that vessel used by pirates (on which, see infra), but the last attempt to describe comprehensively how they were utilised was published in $1924 .{ }^{8}$ Here, I offer an up-to-date overview of the pirate crew's practice so that our understanding of this aspect of the slave supply might be grounded in a firmer appreciation of its practical details. Part II considers the fate of kidnap victims, and takes into its purview the marketing of captives and their chances of ransom or release. No scholar has provided a more sophisticated analysis of Greek piracy than Vincent Gabrielsen, whose work has inter alia addressed the topic of the 'ransom market.' He has shown convincingly that ransoming captives was more profitable that selling them into slavery (Gabrielsen, 2003, p. 392-395). But other considerations beyond profit influenced the decision to engage in ransom negotiations over making off with captives and selling them, and these will form the focus of section II. This will, I hope, contribute to a finer-grained understanding of the circumstances that governed whether captives would enter the broader currents of the slave trade or be re-united with their kin.

\section{The Pirate Crew and its Work}

The phenomenon of piracy in the ancient Mediterranean and adjacent seas was far from uniform. 9 Its most prominent forms in the classical and Hellenistic Aegean, however, shared some common traits and emerged from comparable socioeconomic structures. These structures were widespread in the Aegean before $500 \mathrm{BC}$, and persisted in several regions thereafter. It was the last decades of the sixth century $\mathrm{BC}$ that saw the emergence of large trireme fleets whose efficacy rested on fiscal structures of growing complexity, a phenomenon that developed in tandem with processes of state formation in many of the more advanced city-states. These fleets were state-owned, their crews salaried, and their activities determined by state policy. Prior to these developments, naval violence was largely a private affair: galleys typically rather smaller than triremes

\footnotetext{
8 Ormerod, 1924, p. 13-58. Ferone, 1997, p. 117-137 contains a chapter entitled 'Le imbarcazioni e le techniche di assalto' but largely discusses vessel types. Useful partial discussions can be found in Casson, 1958 and Beresford, 2013, p. 238-257.

9 On the variety of its forms see Garlan, 1978. For Black Sea piracy, see Tsetskhladze, 2000-1.
} 
(such as pentekontoroi and triakontoroi), owned and fitted out by members of the elite for plundering expeditions, and which could be mustered by the emergent states in times of war; but these were not polis-fleets proper (see van Wees, 2013).

As Gabrielsen has shown, the late sixth century to early fifth century represents a turning point, one that saw Greek societies cluster into two camps. ${ }^{10}$ On the one hand were the more politically and economically advanced poleis that maintained state-owned fleets and made the exercise of naval violence into a public monopoly. On the other hand were more traditional communities that cleaved to what Scholten (2000, p. 2) calls the "archaic code of freewheeling, predatory economic self-service”. In such regions, members of the elite still fitted out summer plundering voyages in the time-honoured Homeric manner; it was social conservatism, not social breakdown, that accounts for the association between piracy and regions such as Crete and Aetolia well into the Hellenistic period (cf. Thuc. 1.5.3).11 Beyond Greece proper, similar social structures and behavioural codes existed in the Adriatic; Polybius' (2.8.8) account of the Illyrians under Teuta provides a close parallel for a nascent state that still had not extended its reach over warships and their use. Her reply to the shocked Roman embassy - that it was not the nomimon of the Illyrian monarchs to prevent their subjects from enriching themselves at sea - is symptomatic of a wider archaic worldview that saw the plundering of foreigners by private individuals as beyond the remit of the central authority. ${ }^{12}$ From a fairly early period the Etruscans (Tyrrhenians) were also involved in plundering raids in both the Adriatic and Aegean, and appear as a serious concern for Athenian policy in the fourth century BC (Giuffrida Ientile, 1983).

${ }^{10}$ Gabrielsen, 2001, p. 115-228; 2003, p. 401-403; 2013a, p. 138-147.

${ }_{11}$ Cf. Gabrielsen, 2003, p. 403: "Ultimately, therefore, it was neither political oppression nor poverty that created the predator. Indeed, historically, he had been there all along and continued to enjoy a thriving existence". On piracy as spearheaded by elites in traditional regions, not social outcasts, see further Gabrielsen, 2013a, p. 138: "there is sufficient evidence to show that the cradle of piracy was situated at the upper echelons of sociopolitical structure, whether we call those privileged elites aristocracies or powerholders. It may well be that many of the persons who manned the benches of pirate craft came from the ranks of the destitute and downtrodden. But those commanding the resources needed for owning, maintaining and operating such craft, and also for organizing raiding expeditions, almost certainly belonged to a distinctly higher social class".

${ }^{12}$ See Davies (2004) for a case study, focusing on the career of the Illyrian warlord Demetrius of Pharos. 
An exception to these traditional forms of piracy was the efflorescence of piracy in Cilicia during the second and first centuries BC: its social makeup was quite different, a product of the stresses caused by tectonic shifts among the polities of the Hellenistic Eastern Mediterranean. As Nicholas Rauh (1997) has shown, the Cilician pirates attracted elements of the Mediterranean maritime mob in a manner not dissimilar to early eighteenth century Atlantic piracy; their tactics began, however, along traditional lines and only later developed to mimic those of an established state. 13 The period thus covered in this study saw pirate crews from a variety of regions at large in the Aegean and operating for a variety of reasons, with diachronic shifts in the intensity of raids from this or that quarter.

\subsection{Pirate Galleys: The Tools of the Trade}

The technology in the hands of pirate crews reflected the traditional social structures from which much of this activity emerged. Already in the fifth century BC, when describing the ships of the Trojan War, Thucydides (1.10.4) refers to them as not being like the modern warships of his day, $\dot{\alpha} \lambda \lambda \dot{\alpha} \tau \tilde{\varphi}$ $\pi \alpha \lambda \alpha 1 \tilde{\varphi}$

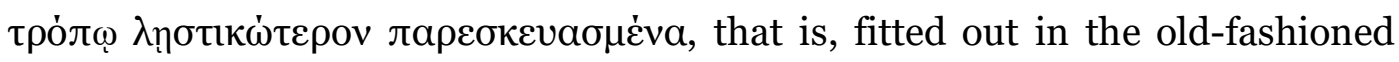
manner of pirate vessels. Their small size (rarely requiring more than fifty oarsmen) and light build (rarely requiring bronze rams: see infra) fitted perfectly the requirements of their practitioners: speed, agility, and concealment. Besides, the archaic custom of dividing booty equally (after setting aside choice prizes for leaders) meant that larger crews meant smaller individual shares. ${ }^{14}$ Yet these vessels were far from antiques, nor did their technological development end in the archaic period. Several new developments illustrate ongoing refinement of these archaic technologies to perform optimally their more specialised role in the classical and Hellenistic period as maritime predators whose prey was shipping and coastal communities. ${ }^{15}$ States too found these vessels useful for irregular

\footnotetext{
13 For Cilicia as a rogue state see Avidov (1998); but the Cilicians' gradual acquisition of state-like trappings does not mean that their reputation for piracy should be dismissed as Roman chauvinism and propaganda.

14 Van Wees, 1992, p. 299-310. This practice persisted among pirates: Ferone, 1997, p. 145-148.

15 Early archaic long ships had to compromise on this principle as they were also used for regular trade: see Hdt. 1.163 on Phocaean pentekontoroi.
} 
warfare. ${ }^{16}$ For these purposes, such vessels were, as J.K. Davies (1984, p. 286) aptly puts it, "in the vanguard of military progress". Four aphract vessel types vie for special comment: the hemiolia, myoparon, lembos, and liburna.

The hemiolia ("one-and-a-half-er") is first mentioned in sources from the late fourth century BC. Theophrastus' stereotypical coward is one who, when at sea, imagines that the headlands that come into view are hemioliai (Char. 25.2). In terms of technical details we are dependent on the name itself: "one-and-ahalf-er" surely derives from the vessel's rowing arrangement, for which there are several possible reconstructions. ${ }^{17}$ One elegant solution to this riddle has the crew rowing all on one level, with a full file of oarsmen along each gunwale and a halffile either side amidships (where the beam is broadest) working in the interstices between the outer file's oars. Figure 1 shows J. F. Coates' reconstruction of a hemiolia based on this hypothesis. ${ }^{18}$ This reconstruction fits with Hesychius' description (s.v. $\dot{\eta} \mu \mathrm{to} \lambda \mathrm{i} \alpha$ ) of the hemiolia as dikrotos, viz. with two longitudinal files of oarsmen per side (Morrison, 1980, p. 122-123). Arrian, in his discussion of Alexander's navigation of the Indus, mentions hemioliai among the triakontoroi (Arr. Anab. 6.5.1); these perhaps utilised a full file of ten oarsmen and a half-file of five oarsmen on each side, totalling thirty oarsmen in all. As with all of these vessel types, however, the number of oarsmen was not fixed but might vary from craft to craft. It is unlikely that hemioliai normally bore bronze rams. ${ }^{19}$

The Cilician pirates began their depredations with small vessels utilising traditional pirate tactics (Plut. Pomp. 24). According to Appian (Mith. 92), they first used hemioliai and myoparones; eventually their power grew to such an extent that they developed the forces and tactics of a fully-fledged state, including large warships and the use of siege warfare. The latter tactics are not of immediate concern here since they represent exceptional rather than quotidian practices. ${ }^{20}$

${ }^{16}$ Casson, 1995a, p. 123-135; Gabrielsen, 1997, p. 90-91.

17 See Casson, 1958; Morrison 1980; Gabrielsen, 1997, p. 89-90; Ferone, 1997, p. 127-133.

18 This reconstruction would be capable of around seven and a half knots at a sprint: Morrison with Coates, 1996, p. 317-319.

19 Appian (Mith. 92) writes that the Cilician pirates first used hemioliai and myoparones, then later dikrotoi and triereis (by dikrotoi he probably means two-level vessels, not double-filed, single-level vessels.) He presents a figure of 71 vessels captured and 306 surrendered during Pompey's campaign (App. Mith. 96). If Plutarch (Pomp. 28) is correct in reporting that 90 of the surrendered vessels bore rams (surely the dikrotoi and triereis), then there would have been 287 ramless galleys in use by the Cilicians in $67 \mathrm{BC}$, most likely made up (for the most part) of hemioliai and myoparones.

20 See Avidov, 1998; cf. Rauh, 1997. 
More to the point is the mention - besides the hemiolia - of the myoparon, another small, swift pirate vessel mentioned on numerous occasions in our sources for piracy in the $2^{\text {nd }}-1^{\text {st }}$ centuries $B C$, most notoriously when the pirate chief Heracleo sailed four myoparones into the harbour of Syracuse under the nose of Sicily's ineffectual governor Verres (Cic. Verr. 2.5.96-8). ${ }^{21}$ Little is known of its design, save that it was a single-level galley and did not usually bear a bronze ram. ${ }^{22}$

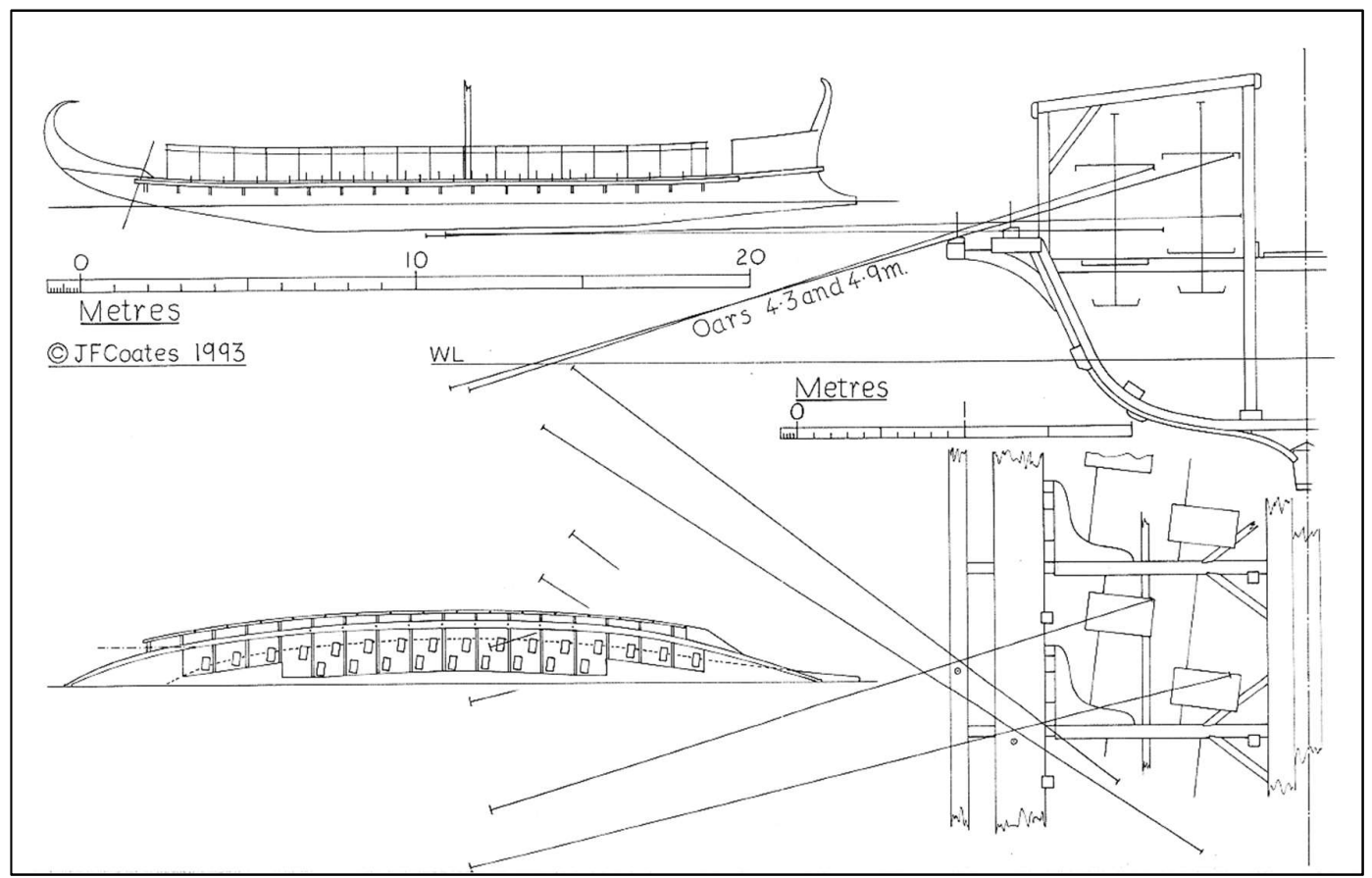

Fig. 1 - J. F. Coates' Reconstruction of a Hemiolia. Source: Morrison with Coates, 1996, p. 318. Courtesy of the Trireme Trust.

The vessel par excellence of Illyrian raiders was the lembos, a term that we first encounter in fourth century Attic sources in relation to tenders for merchant vessels ${ }^{23}$, but which in an Illyrian context refers to a specific kind of raiding galley (Medas, 2004). They were small, swift, and useful for carrying troops, qualities that led Philip V of Macedon to construct 100 of them, though

${ }^{21}$ See also Plut. Luc. 13.3; Cic. Verr. 2.3.186, 2.5.73, 2.5.89; Sallust fr. 3.8 [Maurenbrecher]; Florus 1.41.6.4-6.

${ }^{22}$ See n. 19, but cf. Cic. Verr. 2.1.86-90 for an exception. See further Casson, 1995a, p. 132; Morrison with Coates, 1996, p. 262. A myoparon appears in the Althiburus mosaic: Casson (1995a) fig. 137. The name, like that of the epaktrokeles discussed below, is a compound noun; it means something like "mouse-galley" (a paron being a type of small vessel: Plb. fr. 193; schol. Ar. $\operatorname{Pax}$ 142).

${ }^{23}$ Lycurg. Leoc. 17; Dem. 32.6; 34.10; Anaxandrides fr. 34.7 K-A. 
they were less useful in traditional sea-battles (Plb. 5.109.1-3). Their crews numbered fifty or fewer, and they were normally single-level open galleys; some bore bronze rams. ${ }^{24}$ They became popular with pirates beyond the Adriatic. ${ }^{25}$ Further north along the Adriatic coast lived the Liburnians, an Illyrian tribe who gave their name to the liburna, another famous raiding vessel that was adopted by the Roman fleet as a light craft (App. Ill. 3). The Roman version was rowed at two levels, as Lucan (3.534) and Appian (Ill. 3) make clear; an ancestor of this type is perhaps visible in the fifth century Nesactium relief. ${ }^{26}$

These four vessel types were more modern variants of the small, old-fashioned aphract raiding galleys that Thucydides knew; their capabilities will have been broadly similar. Some pirate crews, however, utilised another kind of vessel: fast variants of the merchant galley type, an intermediary form between the round-hulled merchant ship and the sleek war galley (Casson, 1995b). One type mentioned in fourth century sources (Aeschin. 1.191; Arist. Int. 16a26) is the epaktrokeles, a compound noun evidently based on a better-known kind of merchant galley, the keles, "racehorse", itself used at times by pirates. ${ }^{27}$ The name alone is good evidence for its speed, but the difference between the epaktrokeles and the keles is difficult to establish, and we must fall back on the shaky grounds of etymology. Several solutions have been proposed, but perhaps the term meant

24 In general, see Casson, 1995a, p. 125-127. Crew size: Plb. 2.3.1 has 5,000 Illyrians aboard 100 lemboi, viz. 50 per lembos. Livy (34.35.5) mentions a lembos of 16 rowers, viz. 8 per side. Strabo (2.99) mentions a lembos the equivalent of a penteconter used by the explorer Eudoxus, and two smaller boats resembling pirate lemboi. In Strabo's view, then, a pirate lembos was typically smaller than a penteconter. Single level: Livy (24.40.2) uses the term lembus biremibus on one occasion; the use of the modifier implies that they normally were single-level vessels. Polybius (5.101.2) writes of $\dot{\eta} \mu$ ió $\lambda$ เo $\lambda \dot{\varepsilon} \mu \beta \mathrm{ol}$, lemboi rowed as hemioliai, also evidently exceptional. Ram: pace Casson, 1995a, p. 126 n. 107-108, the fact that Livy (32.32.9) writes of "five lemboi and a ship with a ram" implies that lemboi normally had no ram, but cf. App. Ill. 7 and Plb. 2.12.3 ( $\lambda \dot{\varepsilon} \mu \beta$ ors ... $\dot{\alpha} v o \dot{\pi} \lambda$ oıs), suggesting that ramless lemboi were not standard.

25 Plautus (Bacch. 279-280) describes a long, staunch lembos chasing down a merchantman. Livy (37.27) has a flotilla of pirate lemboi and keletes fleeing to their base at Myonnesus in 190 BC. See also Alciphron 1.6.8; Anth. Pal. 5.44. Lemboi were relatively capacious (Plb. 2.8.4) and could be used as merchant galleys: Casson, 1995b, p. 122. It is generally supposed that the lembos was the vessel of choice of Aetolian pirates (Scholten, 2000, p. 107).

${ }^{26}$ See Panciera, 1956; Morrison with Coates, 1996, p. 316-317; Höckmann, 1997; Medas, 2004; Mihovilić, 2004.

27 Keles: see Casson, 1995a, p. 160-162; Ferone, 1997, p. 124-126. Used by pirates: Thuc. 4.9.1; Livy 37.27. In Heliodorus' Aethiopica (5.22-5) and Thucydides (4.67) pirates use a swift merchant galley type, an akation. The akation was also perhaps used in Hellenistic Crete (if Dindorf's emendation at Diod. 31.38 is correct), as was a vessel called the mydion about which we know little; a rough depiction appears in the Althiburus mosaic (Casson, 1995a, fig. 137). See further Ferone, 1997, p. 120-124. 
nothing more than "hunter-keles". ${ }^{28}$ The capabilities of such vessels were somewhat different than those of the aphract galleys described above, with tactical implications that will be discussed below.

\subsection{The Pirate Galley at Work}

Let us now turn to how these vessels were used in practice. The factor of seasonality is fundamental: although recent work has shown the old view of a fixed sailing season from May to September to be overly rigid, winter sailing could not normally be attempted by most of the kinds of vessel here considered. ${ }^{29}$ It would therefore be a mistake to view Greek piracy as a full-time occupation, at least in most cases. It is equally vital to emphasise pirates' reliance on land bases and their limited range. One reads of Early Modern pirate vessels crossing the Atlantic, rounding Africa and sailing into the Indian Ocean and the waters of Red Sea, staying at sea sometimes for many weeks without making a landfall (Konstam, 2003, p. 5-6). Such feats were impossible for Greek pirates, who, like the skippers of Greek war galleys, had to moor their vessels more-or-less daily. ${ }^{30}$ Although landfalls were vital, we know little about the knowledge that Greek pirates had of good bases. The speaker of [Dem.] 7.3 claims that "all pirates seize places belonging to other people and fortify them, and then from them do

\footnotetext{
${ }_{28}$ Morrison and Williams (1968, p. 245) connect the word to the verb epagein and suggest a small keles that could be hoisted aboard a larger vessel, whilst Casson (1995a, p. 161) thought that the epaktrokeles was "probably designed with greater carrying capacity" than the keles. Although a derivation from epagein is certain, this derivation is clearly not direct: epaktrokeles must derive from a combination of keles and the term epakter, a word that derives itself from epagein but with the apophonic suffix -ter, and means "hunter" in Homeric Greek, in the sense of someone who 'leads on' prey into a trap (cf. Lytle 2018: 83 for the term in fishing). The variant epaktr-is the apophonic zero grade of the full grade غंлактغ่ $\rho$, which is attested also in the term epaktris used for a light vessel by Xenophon (Hell. 1.1.11). As Ferone (1997, p. 126) notes, Nicander (Ther.

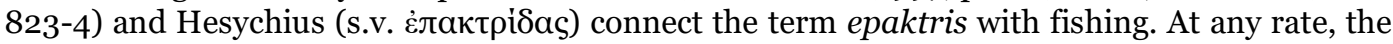
term derives from the pursuit of prey, and as both Plato (Laws 823e) and Aristotle (Pol. 1256a351256b1) liken piracy to hunting animals, it is unclear whether the term epaktrokeles should be associated more with hunting (human) prey or with a specific kind of fishing vessel (my thanks to Mirko Canevaro for discussion of this term).
}

29 Beresford (2013, p. 237-243, but cf. p. 248-255: some pirates did manage to operate to a limited extent in wintertime). "[...] individual Aitolian raiders at this point were in the habit of setting off at the beginning of spring to harass hostile territories and shipping, just as did Illyrians" (Scholten, 2000, p. 150).

30 Their small size and lack of a deck made them very vulnerable to rough seas, e.g. Diod. 31.45: a flotilla of Cretan raiders plunders Siphnos and sails off at night, but is wrecked in a gale. Cf. Arnaud, 2005, p. 34: "Même la piraterie, pour autant que l'on puisse analyser ce phénomène encore mal connu dans le détail, mais qui paraît avoir été particulièrement côtier, n’a probablement pas exercé une influence majeure sur les traversées en haute mer”. 
evil to others”. Indeed, a number of pirate bases are known from our sources. ${ }^{31}$ Some of these were indeed fortified: Livy (37.27; cf. Plb. 21.12) writes of a pirate flotilla of about fifteen galleys, keletes and lemboi which, after plundering the coast of Chios in 190 BC and making off "with all manner of booty" (cum omnis generis praeda), ran into a Roman fleet. The pirates fled to their base at Myonnesus, 'Mouse Island' (mod. Çifitkalesi Adası in Turkey), a rocky promontory jutting into the sea between Teos and Samos (see Morrison with Coates, 1996, p. 107). Although the Romans pursued the raiders to their base, they kept their distance, not wishing to come into range of the pirates posted on the cliffs of the promontory, who were presumably armed with missile weapons (perhaps even artillery). Another notable pirate base was located on the island of Antikythera between Cythera and Crete, superbly situated on the sea-lanes passing between Crete and the southern Peloponnese. This base has been partially excavated. $3^{2}$

At any rate, the important point to emphasise is the pirate's heavy reliance on landfalls. When the Athenians sent a naval force to Caria and Lycia in 430/29 BC to stop Peloponnesian pirates from using it as a base to raid commercial shipping entering the Aegean from Phoenicia and Phaselis, their actions presuppose that it was impractical for these pirates to operate from the Peloponnese itself (Thuc. 2.69; cf. 8.35). They needed a base closer to their hunting grounds. 33 The principle is illuminated in unusual detail in an inscription from Syros dating to the early first century BC (IG XII 5.653 = Bielman, 1994, no. 52 ), which honours a citizen of nearby Siphnos. News of pirates arrived in Syros, and it became clear that they had anchored near Siphnian territory (lines 12-13). They captured two slaves, Noumenios and Botrys, and landed them at a place named Eschatia (lines 25-28); the pirates then landed on an island opposite Siphnian territory (lines 28-29). Noumenios escaped, was captured by the

\footnotetext{
${ }^{31}$ E.g. Alopeconnesus (Dem. 23.166), Halonnesus ([Dem.] 7.2), Euboea (Dem. 18.241), Cythnus (IG II ${ }^{2}$ 682.10), Mycale (Plut. Mor. 303d), Myonnesus between Thessaly and Euboea (Aeschin. 2.72), Myonnesus mod. Çifitkalesi Adası (Livy 37.27; Ephorus FGrHist 70 F 27), Opous (Thuc. 2.32), Scyrus (Plut. Cim. 8.3), Lipari Islands (Livy 5.28.2), Tragia (Strab. 14.1.7) and Pharmacusa (Plut. Jul. 2). For the Cilicians' network of landfalls and bases see Plut. Pomp. 24.3.

32 See Johnston et al., 2012; Baika, 2013, p. 277-283. The Rhodians launched an expedition against Antikythera in the mid-third-century BC (Jacopi, 1932, p. 169 no. 1), almost certainly as an anti-pirate measure. See Bresson, 2007; Sekunda, 2014.

33 Greek pirate galleys thus conformed to the broader limitations of Mediterranean galley usage: (see Pryor, 1995).
} 
honorand, and returned to his master in Syros (lines 29-33). The key point for our purposes is that the pirates' attack was dependent on seizing small, presumably uninhabited islets near their main target and using them as bases, much in the manner described by Pseudo-Demosthenes (7.3). This dependence on a "friendly shore" was shared by Rhodes, the naval prostates ("protector"), whose technology and tactics were not greatly different to those of the pirates: Rhodes established a network of outposts, fanning out across the Aegean, that provided the military infrastructure for anti-pirate expeditions. 34

As we noted earlier, Greek pirates might either chase down vessels at sea or make amphibious descents on coastal towns. We cannot determine the relative frequency of one versus the other kind of venture; our evidence is more heavily weighted towards the latter practice, but these tended to be larger events, more liable to be recorded, and more likely to generate honorific inscriptions if someone were to negotiate the ransom of the prisoners. 35 One thing is certain: the lone pirate galley was less likely to make an amphibious raid than a flotilla of several vessels operating in tandem. ${ }^{36}$ Depending on its size, a coastal settlement might be too risky a target for the lone raider (though a quick razzia into the countryside somewhat less so); and even when we hear of attacks by several vessels, they tend to occur at night when the element of surprise lay with the pirates. 37 If the flotilla were big enough, relatively large towns might even be raided: one inscription from the third century $\mathrm{BC}$ records an attack on Teos in which the pirates kidnapped a number of citizens and held the whole town to ransom for their safe return (SEG 44.949). ${ }^{38}$ Another (SIG3 520 = Bielman, 1994, no. 26) records the capture of some 280 people from Aulon on Naxos by Aetolian raiders. Some coastal communities targeted by pirates fared better: during a night raid by pirates on the harbour at Thera, the Ptolemaic garrison was able to repel the raiders from an area where some 400 people dwelt (IG XII.3 supp. no. 1291). On a rather more modest scale was the attack on the town of Aigiale on Amorgos

34 Gabrielsen, 1997, p. 40-42. On anti-pirate measures see also Zambon, 2004.

35 Pace Casson, 1991, p. 178, merchant vessels were often highly lucrative prizes, e.g. Lys. 23.25; Dem. 24.11-12; [Dem.] 34.37; Theopompus FGrH 115 F 292; cf. Philochorus FGrH 328 F 162, with Bresson, 2000, p. 131-149.

${ }^{36}$ Flotillas: e.g. Hom. Od. 14.248; cf. Thuc. 6.104; IG XII.3 supp. No. 1291.9; Arr. Anab. 3.2.3; Diod. 16.81.3; 20.97.5; 28.1; Plb. 5.95.1; Livy 37.11.6; 37.27.

37 E.g. Hdt. 6.16.2; IG XII.3 supp. no. 1291.14; $S I G^{3} 521.5$.

$3^{8}$ Şahin, 1994; Hamon, 2018. 
by the pirate Sokleidas and his crew in the mid third century BC $(S I G 3521=$ Bielman, 1994, no. 38). They made a night raid into the surrounding countryside and carried off over thirty persons; they then proceeded to steal the ship of a man named Doreios and scuttled the other ships in the harbour. We only know about this episode because two of the captives managed to negotiate the release of the citizen captives from Sokleidas (very probably for a hefty ransom, cf. Roy, 2012, p. 53), and were honoured for their efforts with an inscription. Had this bargain not been struck, the kidnapped men, women and children would surely have ended up in the slave market of some Greek coastal town or city.

Chasing down a merchant vessel at sea presented a rather different prospect, one in which the seamanship of the pirate crew was a crucial factor.39 But we also should bear in mind the capricious element of the weather. It is important to note a basic technological disparity between the hunter and its prey. The pirate galley held the advantage in calm weather: sail-dependent merchantmen were sitting ducks for predators whose oars allowed them to operate efficiently in such conditions, as this epigram illustrates:

Chilling for sailors is the setting of the Kids, but for Pyron the calm was much more hostile than the tempest. For his ship, fettered by a lull in the wind, was run down by pirates in a swift double-banked galley. They killed him; he fled the storm only to meet destruction in the calm. Ah! A baneful, wretched, and unlucky harbour!40

On the other hand, merchantmen could ride out choppy seas with greater ease, conditions that were extremely dangerous for less seaworthy pirate craft, particularly aphract raiding galleys (Beresford, 2013, p. 245). In between these two extremes the outcome of the chase could go either way. A late sixth century black-figure drinking cup from Attica presents a remarkable illustration of this scenario. It depicts a chase between an aphract raiding vessel and a merchant ship in two successive scenes. In the first scene, the merchant has his sails trussed up to the yard, presumably because of a stiff wind. Undeterred by these

\footnotetext{
39 Amateurs who tried their hand at piracy could come to a bad end (see Joseph. BJ 3.9.2 with Ormerod, 1924, p. 30-31).

40 Anth. Pal. 7.640, first century BC. Ormerod, 1924, p. 16. Cf. Heliod. Aeth. 5.23-24 with Beresford, 2013, p. 246-247; Polyaenus 3.11.10, 5.13.1.
} 
conditions, the galley bears down on its prey with its sails set and every man at his oar. In the second scene, the merchant has become aware of the danger and unfurled his sails in a bid to elude his would-be captor, but it appears to be in vain: some of the pirates have shipped their oars in order to shorten sail, and are preparing to board their victim. 41

For pirates aboard merchant galley types, the situation was slightly different. In his Aethiopica, Heliodorus describes the pursuit of a merchantman by pirates using one of the merchant galley types noted above, an akation. ${ }^{42}$ His account usefully illustrates a variation from the situation (described above) concerning aphract raiding galleys. In the story, a merchant vessel has set out from Crete; the steersman has noticed an akation tailing her course and is worried that it might be crewed by pirates (5.22). Some of the passengers tell him not to worry: it is perfectly normal for small vessels to follow the course of larger merchant ships with more experienced navigators. But the fact that the akation's crew are pirates soon becomes apparent: she tails the merchant vessel under sail as long as the wind allows it; when there is a lull, the merchantman is left dead in the water, and the pirates resort to their oars to run her down (5.23). Two observations on this passage are worth underscoring: first, the fact that these vessel types were usually employed for trade lent them a tactically valuable air of innocence not shared by the more obviously predatory aphract raiding galleys; second, their greater seaworthiness made them better suited to operating in windier conditions and on more protracted pursuits.

How the final capture was achieved is somewhat unclear. The pirates who killed Lycon of Heraclea in the Saronic Gulf in the fourth century seem to have borne down on their victim with a hail of arrows (Dem. 52.5). It is possible that one of our best-preserved wrecks, the Kyrenia ship, was once the target of such a volley, as eight javelin tips were discovered under her hull (see Katzev and Katsev, 1986, p. 4-5). Alternatively, the pirate might intimidate the merchant crew with a show of strength but offer to let them go free if they avoided a fight, as Heliodorus

${ }^{41}$ My analysis follows Casson (1958, p. 16). One must make allowance for the small size of the cup, which necessitates some compression of the scene. Morrison's claim (with Coates 1996, p. 183) that the scenes are unrelated due to a slight height difference in the oarsmen of the two scenes presupposes, in my opinion, too scientific an approach on behalf of the artist.

42 The Greek novels include many colourful episodes involving pirates. In terms of verisimilitude some authors fare better than others. For example, Xenophon of Ephesus (1.13, rather improbably) has a crew of Phoenician pirates aboard a trireme posing as merchants. Others are more realistic in their depiction of seafaring (see e.g. Cvikel et al., 2014). 
describes in his Aethiopica (5.24). Capture was most likely achieved with grapnels, cheires siderai ('iron hands'), used as naval weapons in the eastern Mediterranean since the Bronze Age and employed in classical naval warfare. 43 Philostratus (Imag. 1.19.3), indeed, when describing a painting of a pirate galley, mentions among its grisly arsenal grapnels for capturing its prey.

When it came to giving chase the pirate had to use every advantage to gain an edge over his victim: a lengthy pursuit would leave the rowers wilting at their oars, so there was a need to keep the chase as short and as certain as possible. One method that Aegean pirates of the early modern period resorted to involved concealing their vessel behind a headland, keeping watch for victims from the cliffs above, and pouncing at the opportune moment. It is described thus by an English sailor named Roberts:

[...] they go to the Furnoes, and lie there under the high land, having a watch on the hill with a little flag, whereby they make a signal, if they see any sail: they slip out and lie athwart the Boak of Samos, and take their prize; they lie in the same nature under Necaria, and Gadronise [...].44

The same ruse was known in antiquity, and appears as early as Homer. In the Odyssey, the suitors plot to murder Telemachus on his return to Ithaca, and fit out one of their galleys (Od. 4.842-7):

the suitors went aboard and sailed out into the flowing ways, in their hearts devising sudden death for Telemachus.

There is a rocky island there in the middle channel halfway between Ithaca and towering Samos, called Asteris, not large, but it has a double anchorage where ships can be hidden. There the Achaeans waited in ambush.

However, their planned ambush fails to come off. As the suitor Antinoös bitterly comments:

43 Bronze Age: Wachsmann, 1998, p. 317-319; Classical period: Polyaenus 1.40.9; Diod. 13.50.5. See Casson, 1995a, p. 121-2.

44 Hacke, 1699 cited from Ormerod, 1924, p. 17. 
In the daytime we sat watchful along the windy headlands, always succeeding each other, but when the sun set, we never lay through the night on the dry land, but always on the open water, cruising on a fast ship, we waited for divine dawn, watching to ambush Telemachus, so that we could cut him off; but all the time some divinity brought him home (Od. 16.365-70).45

The trick is mentioned in several later authors too, in some cases explicitly associated with pirates. ${ }^{46}$ Its advantage is obvious, for not only does it deny the victim any knowledge about an impending attack until the last moment, but it also allows the chase to be as brief as possible leaving the crew enough energy to board the prize. 47

\section{The Fate of the Captives}

Theophrastus may have thought the fevered imagination of the man at sea who mistook every headland for a hemiolia to be a mark of cowardice, but for sea-goers captured by a pirate galley or coastal-dwellers pounced upon in a pirate raid, real terrors lay in store. That is not to say that the merchantman's submission was a fait accompli (notwithstanding the usual disparity in numbers between the two vessel types' crews, skewed in favour of the pirates). Xenophon (Oec. 8.12) mentions that merchants carried arms to defend themselves at sea, and perhaps some larger, well-armed merchant vessels were too risky a target for a smaller pirate craft operating solo. 48 Certainly, those merchants who could

45 Tr. Lattimore, adapted. The former passage is noted by Ormerod (1924, p. 19).

${ }^{46}$ For pirates see Eur. fr. 669 [Kannicht]; Heliod. Aeth. 5.20; naval tactic: Thuc. 7.4; 8.35; Arr. Anab. 2.1; Xen. Hell. 5.1.27; Hell. Oxy. 4.1; Livy 37.28; Frontin. Str. 3.10.8. Cf. Beresford, 2013, p. 243-245. It could perhaps be a literal allusion to this practice that Douris of Samos (FGrH 76 F13) makes when he compares the Aetolians to the Sphinx sitting perched upon a rock and carrying off any passers-by.

47 Pirates might also seek to obtain intelligence about particularly lucrative targets: apparently, the inhabitants of Corycus would eavesdrop on sailors anchored in nearby ports and pass on intelligence about the richest prizes and their destinations to pirates operating out of Myonnesus, a notorious pirate nest located between Teos and Samos (cf. n. 30) in return for a cut of the loot (Ephorus FGrHist 70 F 27; Strab. 14.1.32; cf. Heliod. Aeth. 5.20).

${ }^{48}$ See further Gianfrotta, 1981. Ferone (1997, p. 121) points to Aristoph. Eq. 761 , where the chorus encourage the Sausage Seller figuratively to protect himself by "raising the dolphin", which Hesychius (s.v. $\delta \varepsilon \lambda \varphi \tilde{v} \varepsilon \varsigma$ ) and Eustathius (1221.25) gloss as a defensive device: "dolphins" were 
afford to take part in naval convoys organised by states such as Athens or Rhodes were extremely well protected against pirates at sea, who must have opted for less prickly targets (Gabrielsen, 2001; 2013b, p. 73-76). Resisting pirates certainly made a good deal of sense: in the early modern age surrendering crews were often incorporated into the pirate's crew 49 - we have, it seems, one instance of this from the Hellenistic Aegean.50 But death or enslavement was a more frequent fate in antiquity. In some cases the victims were simply tossed into the sea to drown by pirates more interested in the cargo than enslaving the crew. ${ }^{1}$ Aristotle

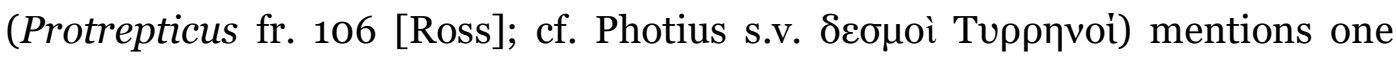
particularly cruel practice, a form of psychological torture inflicted by the Tyrrhenians upon some of their victims, who would be bound face-to-face with rotting corpses. $5^{2}$

The principal aim of pirate crews, though, was to turn a profit; and this brings us to the quandary noted at the beginning of this essay: should the captives be sold or ransomed? In an important contribution, Gabrielsen (2003, p. 394) has argued that the latter "was both substantial and the pirates' favourite", and de Souza (1999, p. 65) has argued that ransom "may even have been the principal aim of much piracy in the Eastern Mediterranean”. Indeed the evidence is unequivocal that ransoming citizens back to their kin was much more lucrative than selling them into slavery (Gabrielsen, 2003, p. 393-394). However, several pragmatic considerations, following from the pattern of practice outlined above, ought to be taken into consideration; and these may lead one to question whether ransom was usually a practical option for pirate crews with a newly-seized haul of captives.

The first is a problem that Gabrielsen (1997, p. 85-111; 2001, passim) has written on at length: the role of the naval prostates. Although it is true that it was

metal weights that could be dropped from the yardarm of a merchant vessel onto a pirate galley to smash through its hull.

49 Mariners were mainly from the lower reaches of the working class, whose families had not the resources to ransom them; and there was no market for kidnapped white mariners as slaves in the Americas (Rediker, 2004, p. 38-59).

5o IG XII.3 no. 328 = Bielman, 1994, no. 54. Discussed at length in Ager (1998).

${ }^{11}$ Anth. Pal. 7.654; Plut. Pomp. 24. State navies could act as cruelly (Xen. Hell. 2.1.31). One Greek term for pirate, katapontistes, literally means 'drowner.'

52 Note that Aristotle had made a particular study of Tyrrhenian customs (Athen. 1.23d; Herakleides Lembos fr. 44 [Dilts]). This Italian form of torture is more vividly related by Virgil (Aeneid 8.485-488). 
not in the prostates' interest to eradicate piracy entirely, ${ }^{53}$ states such as Rhodes posed a serious threat to pirate crews, who might not have the time to enter into negotiations with the relatives of their captives, and may have had to forgo the more profitable option in order to outrun pursuit. As Gabrielsen (2001, p. 237) himself has written, "we are too focused on the victims and captives of the pirates to fully appreciate the fact that the raider's work was not done before he had brought his loot safely to the market, that is, without meeting the ships of the naval prostates; as a profession, leisteia was not entirely free of occupational hazards".

Perhaps more significant than the naval prostates, however, is the fact that the targets of pirate raids were hardly helpless: small poleis and coastal settlements remained armed and dangerous well into the Hellenistic period (Ma, 2000, especially p. 345-361). Inscriptions relating descents by pirates on coastal communities often bear this out. SEG 24.154 (= Bielman, 1994, no. 24; cf. SEG 25:155 = Bielman, 1994, no. 30) honours an Athenian strategos stationed at Rhamnous who protected the surrounding countryside during a pirate raid. Although some persons were captured, he managed to ransom them; but the list of his military preparations shows what the pirates were up against: a garrison along with kryptoi stationed at special vantage points, as well as guard towers and dogs. IG XII.3 supp. no. 1291, noted above, describes how a Ptolemaic garrison successfully repelled an attack by pirates on Thera. SIG 521 (= Bielman, 1994, no. 38), also noted above, describes a raid by the pirate Sokleidas and his crew on Amorgos; the fact that they scuttled all of the ships in the harbour implies that the locals would not have cowered impotently, but would have pursued the pirates if they had the means. IG XII.3 171 (= Bielman, 1994, no. 51) is particularly rich in detail, and describes a piratical descent on the territory of Ephesus in which people and property were carried off from the vicinity of the temple of Artemis Mounychia. On information provided by the Ephesians, individuals from the nearby island of Astyplalea sailed against the pirates, captured many of them, and rescued the Ephesian captives. The pirates were punished "as befitted their

53 "[...] the chaser and those chased were tangled into an intricate relationship of mutual dependence within the same economic and political structure. Elimination of seaborne predatory activity would inevitably mean that the production of protection no longer constituted a paying proposition" (Gabrielsen, 2001, p. 228). 
wickedness".54 This example shows that pirates, despite having valuable captives in their power, were not necessarily in a secure position. One might note that the position of the pirate crew would be much less secure once a ransom had been agreed and the captives returned to their kin; for by this point the pirates would have lost their main point of leverage forestalling retributive action from the victim community. Hellenistic Chios, indeed, seems to have maintained a force of leistophylakika ploia, vessels that specialised in protection from pirates (Skarlatidou, 1993, p. 155-158). What these examples illustrate is that in many cases the pirates were not secure enough in their position to wait around to negotiate a profitable ransom deal, but had to make off in a hurry.55 It was perhaps only in exceptional cases that the pirates were able to do so.

Second is the impetus from which the decision to ransom emerged. The epigraphic evidence contains very few instances of pirates visibly aiming at ransom from the outset. An excellent (and rare) exception is $S E G 44.949$, dating to the third century $\mathrm{BC}$, which records the collection of a colossal ransom (10\% of the citizens' wealth) from Teos: the pirates had raided the town, seized many citizens, and in de Souza's (1999, p. 68) words, "arranged for the Teians to supervise their own ransacking, saving themselves much time, effort and danger by having the plunder collected and delivered to them". That they could allow the citizens nearly a month to gather the ransom shows their confidence in their position; the pirates' force must have been formidable.

Far more common, however, are cases where captives were carried off to be sold in the first instance, and either (i) a well-meaning third party intervened and arranged for their ransom and return, or (ii) the home city of the captives dispatched an embassy to the home city of the pirates to broker a ransom. In some cases the ransom was not negotiated with the captors at all, but set up after the captives had been sold into slavery. Their new owners, sniffing an opportunity to

54 Gabrielsen (2003, p. 398) suggests that they were sold into slavery. Alternatively, they may have been executed. On punishments for pirates see Ferone, 1997, p. 154-156.

55 Julius Caesar's 38 days on Pharmacusa as a captive of Cilician pirates (Plut. Jul. 2.2) occurred at a time when the Cilicians held mastery of the sea. The same conditions cannot be assumed of the third or most of the second century BC. Jim Roy (2012, p. 58) points out to me that in $S I G^{3}$ 521 (= Bielman, 1994, no. 38) the captives are parthenoi and gynaikes, and that the threat of rape meant that getting captive women back quickly was an urgent concern of their families. 
make far more money from the captive than what they had paid for them as a slave, consented, and letters were dispatched to broker the ransom. 56

The importance of the intervention of euergetai can be seen in Dem. 57.18, where we learn of an Athenian captured towards the end of the Peloponnesian War, who ended up serving as a slave in Leucas in western Greece. After many years in slavery, during which he picked up a foreign accent, he met by chance with an actor named Cleander, who arranged for his ransom and return. Although this case did not involve pirates, it shows how ransom negotiations might be entered into not between the original captor and the family or polis of the captive, but at a later point in time through the intervention of a third party. Numerous late-Classical and Hellenistic inscriptions concerning piracy fit this pattern.

Such may be the case with $I G \mathrm{II}^{2} 284$ (= Bielman 1994 no. 5), the full circumstances behind which are not fully clear. Here, Athens honours Cleomis of Methymna for arranging the release of a number of citizens captured by pirates. Evidently, the pirates had not brokered ransom negotiations directly with the Athenians: the release of the captives was effected by the intervention of Cleomis. It is unclear whether or not the citizens had first been sold. Very similar is $I G \mathrm{II}^{2}$ 399 (= Bielman, 1994, no. 6), in which Athens honours Eurylochus for arranging the ransom and return of a number of Athenian citizens taken to Cydonia on Crete. The Cretan connection makes piracy very likely. There is no mention of sale, but again it is the agency of an euergetes that effects the return of the captives. The situation is comparable to $S I G^{3} 535$ (= Bielman, 1994, no. 31), where Athens honours Eumaridas of Cydonia for arranging the ransom and return of numerous citizens who had been captured by Boukris and brought to Crete. Boukris was probably an Aetolian pirate (Scholten, 2000, p. 109); but it is unclear if he was using Crete as a base from which to arrange the ransom with Athens, or as a market to dispose of his captives as slaves, after which point Eumaridas intervened.

Knoepfler, Eretria XI 317.18 (= Bielman, 1994, no. 29) is a decree of Eretria honouring Eudemus of Acarnania for liberating Eretrian prisoners. In the view of Bielman (1994, p. 113), the most likely scenario is that the prisoners were

${ }^{56}$ Gabrielsen (2003, p. 394) rightly compares these to the fate of Nicostratus in [Dem.] 53. On this case see Sosin, 2017. 
captives of Aetolian pirates, sold in Acarnania, at which point Eudemus intervened and arranged their ransom and release. The fact that Eudemus had arranged for the release of some but not all of the captives (line 7) suggests that they had been sold to various owners rather than held together in expectation of a general ransom. The situation is clearer in IG XI 4.1054 (= Bielman, 1994, no. 32): here, Theangela honours Semos, a Delian citizen who bought numerous slaves, the booty of a pirate raid. Semos discovered that two of them were women from a distinguished family in Theangela, and released them. McCabe, Theangela 1 (= Bielman, 1994, no. 40) is a decree of Troezen honouring Aristeides of Theangela, and concerns the liberation of an individual, Charmadas, who had been enslaved by Aetolians: Aristeides, learning of Charmadas' fate, of his own initiative and at his own expense bought him and repatriated him. Bielman (1994, p. 149-150), surely correctly, views these Aetolians as pirates. In all of these cases, there is no sign that the pirates had aimed at ransom from the outset; instead, the ransom was brokered at a later point through the agency of a third party.

Then there are instances where the polis of the captives proactively dispatched an embassy to the home city of the pirates, in order to arrange for the captives' return. In SIG3 244 (= Bielman, 1994, no. 26), Aulon on Naxos honours several of its citizens who had served as ambassadors and had secured the ransom of 280 persons seized in a raid by Aetolians. An embassy despatched to secure the release of captives is also mentioned in a partially damaged decree of Samothrace ( $I G$ XII 8.159 = Bielman, 1994, no. 47). IG XII.3 no. 328 (= Bielman, 1994, no. 54 ) is a difficult document, a letter concerning individuals from Thera who had been captured by pirates from Allaria on Crete. Three years later they had been freed and given land in Allaria. The captives seem actually to have joined the pirates in their activities, though they apparently did not share in the booty. For our purposes, they key point is that the inscription documents diplomatic efforts to repatriate the Theran captives at a much later point in time. 57

Finally, we have the instance, mentioned above, of $S I G^{3} 5^{21}$ (= Bielman, 1994, no. 38), where the impetus to set up a ransom deal came from two of the

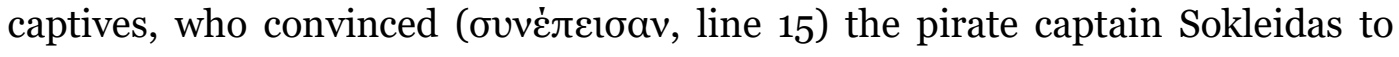
release the captives, presumably for a ransom. Again, we see that the impetus to broker a ransom came not from the pirates but from other parties.

57 Fuller discussion and a novel interpretation in Ager, 1998. 
In sum, the majority of our inscriptions show pirate crews making off quickly with their haul of captives and selling them into slavery. One question quickly springs to mind: is this evidence representative of reality? Not so in Gabrielsen's (2003, p. 394) view: "what we do have a record of are precisely those cases which, by their very nature, were habitually deemed meritorious to be publicized on inscriptions: that is, the intervention of benefactors, collective or individual. What we totally lack (and shall probably never get) is epigraphic evidence for the presumably far superior number of cases of captives being bought back by their own families, something usually not publicized through inscriptions". One can hardly disagree 58 ; but it is important to add a further point, viz. that just as the epigraphic record fails to capture such instances of privatelybrokered ransom, so too must it fail to capture those instances where captives were sold into slavery. The argument about what the epigraphical record leaves in the dark thus cuts in both directions.

My point is not that firm conclusions on the frequency of ransom versus sale can be reached given the state of our sources. Rather, it is that the possibility of sale should not be underestimated, and that risk as much as profit likely governed the pirate crew's decisions in any given instance. The fact that Hellenistic poleis expended much effort to protect their citizens from sale as slaves 59 suggests that enslavement and sale was a very grave risk.

\subsection{Marketing Captives}

This brings us to the final link in the supply chain in which the pirate crew played a direct role: the sale of captives in slave markets. The first pragmatic issue for this stage of the process was the transport of captives; as noted above, most of the craft utilised by pirates (with the exception of merchant galley types) were not built for carrying cargo. The keletes and lemboi mentioned by Livy as operating out of Myonnesus in $190 \mathrm{BC}$ would have been better placed to carry booty than vessels such as myoparones and hemioliai (see n. 25 and 27). According to Hypereides (On Protection Against the Tyrrhenians fr. 166 [Blass]), Tyrrhenian

\footnotetext{
${ }^{8}$ Although one practical point: can we imagine pirates conducting simultaneously many negotiations with the families of each individual captive seized in a raid? This would have complicated the process of negotiation immensely.

59 See Kvist, 2003 for Cretan grants of asylia; more generally, see Roy, 2012.
} 
pirates used, alongside their galleys, special ships called komistika ploia, 'transport ships', which Hesychius glosses as auxiliary vessels for transporting captured loot. We lack evidence for similar strategies pursued by Greek pirates although the fact that Sokleidas' gang in $S I G^{3} 5^{21}$ stole the ship of Doreios may similarly be due to their haul of over 30 captives, who may not have been easy to carry away on the vessel(s) in which the pirates arrived. At any rate, the technology at the disposal of pirates may have influenced their preference for human captives over other kinds of booty, for the former had a very favourable bulk and weight to value ratio, and could be rapidly moved on board prior to a hasty getaway (Gavriljuk, 2003, p. 79-80).

Rostovtzeff's (1941, p. 196) remark that pirates "were welcomed in all commercial ports when they appeared laden with their booty" is unsatisfactory for several reasons. First, it looks very much like an unwarranted extrapolation of Strabo's (14.5.2) remarks about late Hellenistic Delos. Second, it ignores openly hostile poleis such as Athens and Rhodes (at the least) which were no friends to the pirate crew. Third, it is doubtful that most commercial ports would be anything other than alarmed by the arrival of a flotilla of craft of the sort described above, which further suggests the additional use of general merchant vessels for disposing of captives in ports other than the home ports of the pirate crews (in e.g. Crete or Aetolia). In other words, pirates may well have seized more innocentlooking craft (such as the ship of Doreius noted in $S I G^{3} 521$ ) or utilised more practical craft (such as the Tyrrhenian komistika ploia) if they intended to market their captives somewhere other than their home ports. A further possibility, though one for which we lack evidence, lies in contacts between pirate crews and slave traders, which could allow the pirate to dispose of his haul of captives without the risk of sailing to a given port (Gabrielsen, 2003, p. 394). It is a mark of the difficulty of the evidence that the significance of this option, potentially important, cannot be assessed on the evidence that we have. Nevertheless, we do hear of ports welcoming pirates and providing a market for pirate booty: two fifth-century Athenian inscriptions explicitly forbid allied poleis from doing this (IG I3 67.7-9; 75.6-10), and in the following century we hear complaints that the Thasians and Melians had done precisely such a thing (Dem. 12.2; 58.56). How did pirate crews know where they would find a safe harbour and market for their captives, beyond returning to their home ports? 
A comprehensive answer is not possible; but some considerations on the identity of pirate crews and especially their leaders may suggest fruitful lines of enquiry. As Gabrielsen has shown, it is a mistake to view the social context of most (pre-Cilician) piracy in the Aegean in terms of marginal or excluded groups. Pirate galleys were, by and large, owned, fitted out, and their crews led by elite men from Greek communities that never gave up the archaic practices and attitudes of private raiding. Their predilection for raiding should not been seen as an exclusive role. Even in Homer (Od. 1.184) a raider chief can also be a trader in metals. Likewise, it is well known that early Greek mercenaries were recruited not from an "open market" but through aristocratic xenia networks (whence the word xenos gained the auxiliary meaning of "mercenary"). The same individuals could toggle between these different roles and identities as and when required. The best way to explain the later situation is in terms of long-term continuities from the archaic era, where leading men could go raiding with their hetairoi, help out one of their guest friends by supplying them with armed men (themselves and their hetairoi) in return for a misthos, and indeed dabble in trade.

This multiplicity of roles that individuals from traditional regions might switch between is evident in Classical and Hellenistic sources. For instance, there is no reason to think that the social origins of Cretan mercenaries - much in demand as archers who specialised in skirmishing tactics over broken ground were any different from Cretan pirates. ${ }^{60}$ The early-Hellenistic archipeiratai are another case in point. We hear of a number of such "pirate chiefs" serving as mercenaries in the wars of the Successor Kingdoms (see Gabbert, 1986). Some have suggested that these were "ex-pirates" (Gabbert, 1986, p. 160), but that is to mistake the nature of the problem: the Greek terms leistes and peirates were not legal statuses or categorisations bestowed for violating international law, but were terms used for functional reasons connected with the strategy of the plundering raid. This might include individuals that made this their habitual activity (i.e. pirates sensu stricto); but the same terminology could be used for troops of states at war who resorted to the tactics of the plundering raid, or

60 Training in irregular warfare: Plat. Leg. 625c-626b; Ephorus FGrHist 70 F 149; Cretan mercenary archers: Thuc. 6.25.2; 6.43; 7.57.9-10; Xen. Anab. 1.2.9; 3.3.7; 3.3.15; 3.4.17; 4.2.27-8; 5.2.29-32; Hell. 4.2.16; 4.7.6; Plb. 4.20.6-12; 4.54-5; 4.67.3; 4.68.3; 5.3.2; 5.14.1; 5.79.10; 17.57.4; 20.85.3; Arr. Anab. 1.8.3-5; 2.7.7-8; 2.9.3; 3.5.6. On Cretan piracy in general, see Brulé, 1978. 
individuals who practised plundering raids for a limited period of time before reverting to more "formal" methods of warfare.

My point here is that we should not assume that early Greek traders, mercenaries, and pirates were always distinct occupations practised by different individuals. As Luraghi (2006) has shown, the same individual could toggle between each role. The same was probably true in later times, and this may provide the key for understanding how pirate crews were able to dispose of their booty in markets other than their home ports. For these crews were generally not (Tyrrhenians excepted) barbarian outsiders intruding into the Greek world, but a long-established component of it. Just as enterprising elite men of the archaic period were typically well-travelled and well-connected with their peers elsewhere in the Aegean world, their successors in traditional Greek communities of later periods probably had social connections in other regions, and carried a fund of knowledge on landfalls, safe harbours, legitimate and lucrative targets, and friendly markets. It was such connections that enabled them to be in contact with, for example, Hellenistic kings in need of their expertise in irregular warfare; or indeed, in touch with states such as Athens, as was the Euboean condottiere and warlord Charidemus, who was accused of starting his career as a mercenary light-infantryman before acquiring a pirate ship and preying on Athens' allies (Dem. 23.148). Aetolians and the Aetolian koinon of the third century BC were thoroughly familiar with (and connected to) the broader Aegean world (Funke, 2008). Even in fairly developed regions, the temptation for leading men to resort to the old-fashioned life of a raider was hardly out of the question: such was the decision of the Phocaean admiral Dionysius following the Battle of Lade (Hdt. 6.17), and in later centuries we find so-called pirate leaders from various poleis including Miletus (Xen. Hell. 2.1.30), Chalcis (Livy 31.22), Sparta (Livy 37.13.1114.1; Plb. 5.3.7), and Methymna (Arr. Anab. 3.2.4). Even in fourth-century Athens, one individual seems to have acquired a naval-surplus trireme and headed with it to Crete to serve as a mercenary commander (Casson, 1995c). In such instances the distinction between war and piracy was murky, and slippage between the two could easily occur. The difference was not between the individuals who practised these activities, but was a matter of their tactics, targets, and relations with states at war at a given point in time. 


\section{Conclusions}

Thinking away our received cultural baggage associated with Atlantic piracy of the seventeenth and eighteenth centuries is crucial for grasping the social character and practical operation of piracy in the ancient Greek world. Rather than representing moral or economic breakdown, privately-organised raiding was, generally speaking, a traditional activity that certain Greek communities simply never gave up - although Greeks who penned most of our sources came from more economically and politically advanced communities that found such practices backwards, abhorrent, and illegitimate. Nevertheless, piracy was a fundamental component of the ancient Greek economy. It redistributed commodities by force more often than destroying them altogether; but it also actively commoditised human beings, tearing them from the ships on which they sailed or the coastal communities in which they lived and turning them literally into "human capital" that could be traded in slave markets. That is not to say that piracy was a straightforwardly productive feature of the ancient economy: it certainly raised transaction costs for interstate trade, ${ }^{61}$ never mind blighting the lives and fortunes of their victims and their victims' communities. At any rate, study of its practical aspects underscores its importance to the history of labour in the Greek world; for not only did piracy involve skilled work itself, but it also produced labour through the enslavement of its victims. The ransom market did to some degree siphon off a proportion of those captives and return them to their kin; but it likely that the stock in trade of the typical pirate crew was enslavement, theft, and murder; a pursuit that was followed each summer in the Eastern Mediterranean for centuries until the fleet of Pompey brought it to an end in 67 BC.

Article received in 21.03.2019, approved in 11.04.2019

\section{BIBLIOGRAPHICAL REFERENCES}

Ager, S. Thera and the Pirates: An Ancient Case of the Stockholm Syndrome? Ancient History Bulletin, vol. 12, 1998, p. 83-95.

61 The remarks of Bresson, 2016, p. 302-305 strike me as completely correct. 
Arnaud, P. Les routes de la navigation antique: itinéraires en Méditerranée. Paris: Errance, 2005.

Avidov, A. Were the Cilicians a Nation of Pirates? Mediterranean Historical Review, vol. 12, 1997, p. 5-55.

Avram, A. Some Thoughts about the Black Sea and the Slave Trade before the Roman Domination (6 $6^{\text {th }} 1^{\text {st }}$ centuries BC). In: Gabrielsen, V.; Lund, J. (eds.) The Black Sea in Antiquity: Regional and Interregional Economic Exchanges. Aarhus: Aarhus University Press, 2007, p. 239-251.

Baika, K. The Fortification of Shipsheds and Naval Arsenals. In: Blackman, D.; Rankov, B. Shipsheds of the Ancient Mediterranean. Cambridge: Cambridge University Press, 2013, p. 185-209.

Beresford, J. The Ancient Sailing Season. Leiden: Brill, 2013.

Bielman, A. Rétour à la liberté: libération et sauvetage des prisonniers en Grèce ancienne. Athens: École Française d'Athènes, 1994.

Braccesi, L. (ed.) La pirateria nell'Adriatico antico. Rome: L'Erma di Bretschneider, 2004.

Bresson, A. La cité marchande. Bordeaux: Ausonius Éditions, 2000.

. Rhodes, Rome et les pirates tyrrhéniens. In: Brun, P. (ed.) Scripta Anatolica: Hommages à Pierre Debord. Bordeaux: Ausonius, 2007, p. 145-64.

. The Making of the Ancient Greek Economy: Institutions, Markets, and Growth in the City-States. Princeton: Princeton University Press, 2016.

Brulé, P. La piraterie crétoise hellénistique. Paris: Les Belles Lettres, 1978.

Casson, L. Hemiolia and Triemiolia. Journal of Hellenic Studies, vol. 78, 1958, p. 14-18.

. The Ancient Mariners. Princeton: Princeton University Press, 1991.

Ships and Seamanship in the Ancient World. Revised Edition. Baltimore: Johns Hopkins University Press, 1995a.

. Merchant Galleys. In: Gardiner, R. (ed.) The Age of the Galley. London: Conway Maritime, 1995b, p. 117-126. p. 241-245.

A Trireme for Hire (Is. 11.48). Classical Quarterly, vol. 45, n. 1, 1995c,

Crisculo, L. Ptolemies and Piracy. In: Buraselis, K.; Stefanou, M.; Thompson, D. J. (eds.) The Ptolemies, the Sea and the Nile: Studies in Waterborne Power. Cambridge: Cambridge University Press, 2013, p. 160-171.

Cvikel, D.; Kahanov, Y.; Rosen, B.; Saaroni, H.; Galili, E. The Voyage of Leucippe and Clitophon: A New Interpretation. Mariner's Mirror, vol. 100, n. 4, 2014, p. 388-404. 
Davies, J.K. Cultural, Social and Economic Features of the Hellenistic World. Cambridge Ancient History, Vol. VII.1. Second Edition. Cambridge: Cambridge University Press, 1984, p. 257-320.

Davies, J.K. Demetrio di Faro, la pirateria e le economie ellenistiche. In: Braccesi, L. (ed.) La pirateria nell'Adriatico antico. Rome: L'Erma di Bretschneider, 2004, p. 119-127.

de Souza, P. Piracy in the Graeco-Roman World. Cambridge: Cambridge University Press, 1999.

Ferone, C. Lesteia: forme di predazione nell'Egeo in età classica. Napoli: Procaccini, 1997.

Finley, M. I. The Black Sea and Danubian Regions and the Slave Trade in Antiquity. Klio, vol. 40, 1962, p. 51-59.

Fischer, J. Der Schwarzmeerraum und der antike Sklavenhandel. Bemerkungen zu einigen ausgewählten Quellen. In: Frass, M.; Graßl, H.; Nightingale, G. (eds.) Akten des 15. Österreichischen Althistorikertages Salzburg, 20.-22. November 2014. Salzburg: Paracelsus, 2016, p. 53-71.

Funke, P. Die Aitoler in der Ägäis. Untersuchungen zur sogenannten "Seepolitik" der Aitoler im 3. Jh. v. Chr. In: Winter, E. (ed.) Vom Euphrat bis zum Bosporus. Kleinasien in der Antike. Festschrift für Elmar Schwertheim zum 65 . Geburtstag. Bonn: Habelt, 2008, p. 253-267.

Gabbert, J. Piracy in the Early Hellenistic Period: A Career Open to Talents. Greece \& Rome, vol. 33, n. 2, 1986, p. 156-163.

Gabrielsen, V. The Naval Aristocracy of Hellenistic Rhodes. Aarhus: Aarhus University Press, 1997.

- Economic Activity, Maritime Trade and Piracy in the Hellenistic Aegean. Revue des Etudes Anciennes, vol. 103, 2001, p. 219-240.

. Piracy and the Slave Trade. In: Erskine, A. (ed.) A Companion to the Hellenistic World. Oxford: Blackwell, 2003, p. 389-404.

. Warfare, Statehood, and Piracy in the Greek World. In: Jaspert, N.; Kolditz, S. (eds.) Seeraub im Mittelmeerraum. Piraterie, Korsarentum und maritime Gewalt von der Antike bis zur Neuzeit. Paderborn: Verlag Ferdinan Schöningh, 2013a, p. 133-153.

. Rhodes and the Ptolemaic Kingdom: The Commercial Infrastructure. In: Buraselis, K.; Stefanou, M.; Thompson, D. J. (eds.) The Ptolemies, the Sea and the Nile: Studies in Waterborne Power. Cambridge: Cambridge University Press, 2013b, p. 66-81.

Garlan, Y. Signification historique de la piraterie grecque. Dialogues d'Histoire Ancienne, vol. 4, 1978, p. 1-16.

. War, Piracy and Slavery in the Greek World. In: Finley, M. I. (ed.) Classical Slavery. London: Psychology Press, 1987, p. 7-21. 
Gavriljuk, N. The Graeco-Scythian Slave Trade in the $6^{\text {th }}$ and $5^{\text {th }}$ Centuries BC. In: Bilde, P. G.; Hojte, J. M.; Stolbe, V. F. (eds.) The Cauldron of Ariantas: Studies Presented to A. N. Sceglov on the Occasion of his $75^{\text {th }}$ Birthday. Aarhus: Aarhus University Press, 2003, p. 75-85.

Gianfrotta, P. Commercio e pirateria: prime testimonianze archeologiche sottomarine. Mélanges de l'école française de Rome: Antiquité, vol. 93, 1981, p. 227-242.

Giuffrida Ientile, M. La pirateria tirrenica: momenti e fortuna. Rome: G. Bretschneider, 1983.

Grieb, V.; Todt, S. (eds) Piraterie von der Antike bis zur Gegenwart. Stuttgart: Franz Steiner Verlag, 2012.

Hacke, W. A Collection of Original Voyages. London: James Knapton, 1699.

Hamon, P. Tout l'or et l'argent de Téos: au sujet d'une nouvelle édition des décrets sur les pirates et l'emprunt public pour la libération des otages. Chiron, vol. 48, 2018, p. 333-374.

Höckmann, O. The Liburnian: Some Observations and Insights. International Journal of Nautical Archaeology, vol. 26, 1997, p. 192-216.

Jacopi, Giulio. Nuove epigrafi dale Sporadi Meridionali. In: Maiuri, Amedeo (org.) Monumenti di scultura del Museo Archeologico di Rodi. Bergamo: Istituto Storico-Archeologico, 1932, p. 165-256.

Jaspert, N.; Kolditz, S. (eds.) Seeraub im Mittelmeerraum. Piraterie, Korsarentum und maritime Gewalt von der Antike bis zur Neuzeit. Paderborn: Verlag Ferdinan Schöningh, 2013.

Johnston, A., Quercia, A., Tsaravopoulos, A., Bevan, A.; Conolly, J. Pots, Piracy and Aegila: Hellenistic Ceramics from an Intensive Survey of Antikythera, Greece. Annual of the British School at Athens, vol. 107, 2012, p. 247-272.

Katzev, M. L.; Katzev, S. Kyrenia II: Research on an Ancient Shipwreck comes Full Circle in a Full-Scale Replication. Institute of Nautical Archaeology Newsletter, vol. 13, n. 3, 1986, p. 1-11.

Konstam, A. The Pirate Ship 1660-1730. Oxford: Osprey Publishing, 2003.

Kvist, K. Cretan Grants of Asylia: Violence and Protection as Interstate Relations. Classica et Mediaevalia, vol. 54, 2003, p. 185-222.

Lewis, D. M. Near Eastern Slaves in Classical Attica and the Slave Trade with Persian Territories. Classical Quarterly, vol. 61, n. 1, 2011, p. 91-113.

- The Market for Slaves in the Fifth- and Fourth-Century Aegean: Achaemenid Anatolia as a Case Study. In Harris, E. M.; Lewis, D. M.; Woolmer, M. (eds.) The Ancient Greek Economy: Markets, Households and City-States. Cambridge \& New York: Cambridge University Press, 2016, p. 316-336. 
. Notes on Slave Names, Ethnicity, and Identity in Classical and Hellenistic Greece. Studia Źródłoznawcze: U Schyłku Starożytności, vol. 16, 201a, p. 169-199.

. Greek Slave Systems in their Eastern Mediterranean Context, c. 8oo146 BC. Oxford: Oxford University Press, 2018b.

Luraghi, N. Traders, Pirates, Warriors: The Proto-History of Greek Mercenary Soldiers in the Eastern Mediterranean. Phoenix, vol. 6o, 2006, p. 21-47.

Lytle, E. Fishing with Fire: Technology, Economy, and Two Inscriptions. Historia, vol. 67, n. 1, 2018, p. 61-102.

Ma, J. Fighting Poleis of the Hellenistic World. In: van Wees, H. (ed.) War and Violence in Ancient Greece. London: Classical Press of Wales, 2000, p. 337-376.

Medas, S. $\Lambda \dot{\varepsilon} \mu \beta o r$ e liburnae. In: Braccesi, L. (ed.) La pirateria nell'Adriatico antico. Rome: L'Erma di Bretschneider, 2004, p. 129-138.

Mihovilić, K. La situla di Nesazio con naumachia. In: Braccesi, L. (ed.) La pirateria nell'Adriatico antico. Rome: L'Erma di Bretschneider, 2004, p. 93-107.

Milton, G. White Gold. London: Farrar, Straus and Giroux, 2004.

Morrison, J. S. Hemiolia, Trihemiolia. International Journal of Nautical Archaeology, vol. 9, 1980, p. 121-126.

Morrison, J. S.; Williams, R. T. Greek Oared Ships. Cambridge: Cambridge University Press, 1968.

Morrison, J. S.; Coates, J. Greek and Roman Oared Warships. Oxford: Oxbow Books, 1996.

Ormerod, H. A. Piracy in the Ancient World. Liverpool: Liverpool University Press, 1924.

Panciera, S. Liburna: rassegna delle fonti, caratteristiche della nave, sccezioni del termine. Epigraphica, vol. 18, 1956, p. 130-156.

Perrier, A. Brigands et pirates. In: Picard, O., Brunet, M., Couvenhes, J.C., Perrier, A., Prêteux, F.; Rebuffat, F. (eds.) Économies et sociétés en Grèce ancienne (478-88 av. J.-C.). Paris: A. Coulin, 2008, p. 212-234.

Pryor, J. H. Geographical Conditions of Galley Navigation in the Mediterranean. In: Gardiner, R. (ed.) The Age of the Galley. London: Conway Maritime, 1995, p. 206-216.

Rauh, N. Who Were the Cilician Pirates? In: Swiny, S. et al. (eds.) Res Maritimae: Cyprus and the Eastern Mediterranean from Prehistory to Late Antiquity Atlanta: Scholars Press, 1997, p. 263-283.

Rediker, M. Villains of All Nations: Atlantic Pirates in the Golden Age. Boston: Beacon, 2004. 
Rediker, M. The Slave Ship: A Human History. London: Penguin Books, 2007.

Rostovtzeff, M. The Social and Economic History of the Hellenistic World. Volume I. Oxford: Oxford University Press, 1941.

Roy, J. Cittadini ridotti in schiavitù: il consolidarsi della schiavitù nella Grecia classica. In: Di Nardo, A.; Lucchetta, G. A. (eds.) Nuove e antiche schiavitu. Napoli: Editoriale Scientifica, 2012, p. 53-63.

Şahin, S. Piratenüberfall auf Teos: Volksbeschluss über die Finanzierung der Erpressungsgelder. Epigraphica Anatolica, vol. 23, 1994, p. 1-36.

Scholten, J. The Politics of Plunder: Aitolians and their Koinon in the Early Hellenistic Era, 279-217 B.C. Berkeley: University of California Press, 2000.

Sekunda, N. A Note on the Rhodian Expedition against Aigila. Grammateion, vol. 3, 2014, p. 13-14.

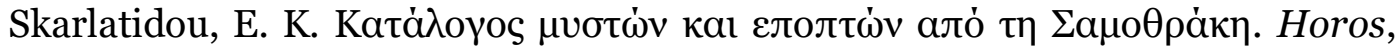
vol. 8-9, 1993, p. 153-172.

Sosin, J. Ransom at Athens ([Dem.] 53.11). Historia, vol. 66, 2017, p. 130-146.

Tsetskhladze, G. R. Black Sea Piracy. Talanta, vol. 32-33, 2000-2001, p. 308-315.

Velkov, V. Zur Frage der Sklaverei auf der Balkanhalbinsel während der Antike. Etudes Balkaniques, vol. 1, 1964, p. 125-138.

Vitkus, D. J. Piracy, Slavery, and Redemption: Barbary Captivity Narratives from Early Modern England. New York \& Chichester: Columbia University Press, 2001.

Vlassopoulos, K. Two Images of Ancient Slavery: The "Living Tool" and the "Koinônia". In: Hermann-Otto, E. (ed.) Sklaverei und Zwangsarbeit zwischen Akzeptanz und Widerstand. Hildesheim, Zürich \& New York: Olms Georg AG, 2011, p. 467-477.

van Wees, H. Status Warriors: War, Violence and Society in Homer and History. Amsterdam: J. C. Gieben, 1992.

. Ships and Silver, Taxes and Tribute: A Fiscal History of Archaic Athens. London: I. B. Tauris, 2013.

Wachsmann, S. Seagoing Ships \& Seamanship in the Bronze Age Levant. London: Texas A\&M University Press, 1998.

Wiemer, H.-U. Krieg, Handel und Piraterie: Untersuchungen zur Geschichte des hellenistischen Rhodos. Berlin: De Gruyter, 2002.

Zambon, E. I Provvidimenti ontro i pirati in età ellenistica. In: Braccesi, L. (ed.) La pirateria nell'Adriatico antico. Rome: L'Erma di Bretschneider, 2004, p. 147172. 